\title{
The Struggle to Save the Soviet Economy: Mikhail Gorbachev and the Collapse of the USSR
}

Review Number: 2066

Publish date: Thursday, 16 February, 2017

Author: Chris Miller

ISBN: 9781469630175

Date of Publication: 2016

Price: $£ 25.00$

Pages: 256pp.

Publisher: University of North Carolina Press

Publisher url: https://www.uncpress.org/book/9781469630175/the-struggle-to-save-the-soviet-economy/ Place of Publication: Chapel Hill, NC

Reviewer: Isaac Scarborough

In the West, it can be easy to forget just how closely China and the USSR were once bound in political imaginations. Today, the USSR is a land to which there is no return: a figment of past dreams and nightmares - whereas China is on everyone's mind, a growing economic power that has shed its socialist past to move to the forefront of the new capitalist order. There seems little to link the two countries together. In the former USSR itself, however, the divide is far less obvious. Academic conferences in Central Asian capitals, nominally dedicated to regional economic integration, have a tendency to devolve into heated debates about how the USSR 'should have followed the Chinese path', and Russian economists continue to draw parallels between the two countries. For those who lived through the Soviet collapse, China remains the example of what could have been - the promised land of economic growth and plenty that Mikhail Gorbachev talked about throughout the 1980s, but just couldn't deliver.

In this light, Chris Miller's decision to return to the China-USSR comparison in his analysis of the Soviet collapse seems both prescient and apt. Reconsidering the economic reforms of perestroika 25 years after the final disintegration of the USSR, Miller's The Struggle to Save the Soviet Economy asks why it was that China and the USSR, following relatively similar reform programs in the 1980s, end up in quite such different places by the early 1990s. In order to answer this central question, Miller dives into the debates surrounding the economic reform program proposed and implemented by Gorbachev under the heading of 'perestroika' in the mid-to-late 1980s. Considering both the Soviet reforms themselves and their similarities to contemporary Chinese initiatives, Miller ultimately argues that the fundamental difference between the two socialist systems - the flaw that sent the Soviet train off the rails - was political, rather than economic. Soviet reforms failed in the face of Chinese success because Gorbachev was restricted in his ability to reform: the Soviet system was far more bureaucratic and centralized control more limited. 'Powerful interest groups obstructed Gorbachev's policies’ (p. 261), leading to political indecision and inaction, over-spending, and ultimately collapse.

Much more of an intellectual and political history of economic reform than an economic history of perestroika, Miller's work avoids any detailed comparison of Soviet and Chinese reform measures - or, for that matter, any extensive statistics about Soviet economic performance. Instead, the focus is on the political 
debates in Moscow: how Gorbachev and his advisors approached the need for reform and to what, in their estimation, the reforms led. This also includes the role of Soviet academics in emphasizing the changes occurring parallel in China at the time and the clear overlap between Chinese reforms and the program that Gorbachev had in mind. Miller effectively demonstrates the impact of China (and the Soviet Chinese analysts) on Gorbachev's thinking, as well as how China played the dual role of an example of reform and a 'trump card' (p. 148) against those who opposed marketization. When Gorbachev's push for private enterprises - the so-called 'cooperatives' - or market-like enterprise incentives were questioned, he could always point to China's success and economic growth, built, it would have seemed, on the back of very similar economic reforms.

Using the contemporary China-USSR comparison as a structural backbone, The Struggle to Save the Soviet Economy is built around a series of both chronologically and thematically organized chapters. While not organized into explicit sections, the book could easily be divided into two: first, the background to perestroika and how China played an important role in engendering Soviet reform (chapters one to three); and second, the content and consequences of Soviet reform (chapters four to seven). Moving forward in time to 1991 as well as thematically from the broader politics of reform debates in Moscow to the particulars of perestroika's reforms, the book is elegantly and smoothly structured, and there is little difficulty following the larger argument about the plausibility of reform in the USSR and the cost of lost (Chinese) opportunities. Clearly written and devoid of extended statistical asides, moreover, the work makes for a both accessible and fulfilling history: readers gain a distinct impression of the reformists and conservatives arguing away in Moscow in the late 1980s. For a book focused on the history of economic reform, this liveliness of tone is much to its credit.

In the first provisional section (chapters one to three) of his book, Miller describes how, in its search for models of economic reform, Gorbachev and his team of advisors came to embrace the ideas embodied by Deng Xiaoping's new China of the 1980s. Working with both Politbureau minutes and memos from Soviet academic memos produced in the Academy of Sciences of the USSR, he demonstrates the influence and importance of China as a leading and growing economic power. These 1980s analyses of China's growth are also helpfully situated in a broader history of Soviet observations of China, providing background and context to the debates of the 1980s. Finally, chapter three sets the stage for Gorbachev's struggle with 'industrial enterprises' and 'powerful interest groups' (p. 87) in order to affect change in some way approximate to the Chinese model. In Miller's estimation, Gorbachev was hamstrung from the start by the entrenched power of Soviet industrial ministries, the military-industrial complex, and the all-seeing bureaucratic class. As a result, he suggests, perestroika was from the beginning hijacked by numerous lobbies and used as an excuse to increase already out of control state spending, running up the budget deficit from 1985 on.

Moving on to the content of Soviet economic reforms during perestroika, the second section of Miller's work (chapters four to seven) highlights both the links between Gorbachev's reform ideas and Chinese modifications to the socialist model and the difficulties he faced in making them a reality. Chapter four considers the struggle to implement changes to enterprise law, as well as the 1986 Soviet Law on Individual Labor Activity, the Law on Cooperatives, and the ultimate 1987 Law on State Enterprises. Chapter five follows a similar structure in its analysis of the USSR and China's parallel experiments with 'special economic zones' and joint foreign-local enterprises, while chapter six moves on to agricultural reform during the perestroika era. Somewhat controversially, Miller argues that Gorbachev did in fact have an extensive plan for agricultural change, but that these plans, as with industry, were foiled by entrenched bureaucratic interests; he also links these plans to contemporary Chinese reforms of the countryside. All of these failed attempts to initiate real and lasting reform to the Soviet economy, Miller argues in chapter seven, resulted in a paralyzed political sphere, lack of any real change, and increasing inflation as the state struggled to stay afloat, treading water by printing money instead of addressing the real economic problems of the day. 'As the money supply spiraled inexorably upward, political conflict sharpened, leading to a military coup and the collapse of the Soviet state' (p. 216). 
In both the conclusion to The Struggle to Save the Soviet Economy and throughout his book, Miller emphasizes the important role of monetary policy and inflation in bringing down the USSR. China, he states, was able to control its inflationary issues - whereas the Soviet Union, held down by powerful industrial interests, was not. The budget overhang forced the USSR to print money, leading to inflation; inflation made it 'far less worthwhile for ... enterprises to sell things' (p. 102). Thus production continuously fell throughout perestroika, exacerbating deficits and shortages and only making the collapse of the entire system that much more likely. Ultimately, no matter the efforts Gorbachev made to save the Soviet Union, it was all for naught: brought down by the weight of its own 'industrial behemoths and collective farms' (p. 221), the USSR splintered and collapsed.

On one level, Miller tells a convincing and elucidating story about the end of the Soviet Union. Joining the growing scholarly consensus that the causes of the Soviet collapse should be sought not in the 'fundamental flaws' of the system, but rather the period of its collapse itself, Miller emphasizes the politics and economic lobbying alive in Moscow throughout the late 1980s. He is quite right to highlight the many interests that affected perestroika reforms, as well as the fact that 'politics and economics were interlinked' (p. 262) simple arguments about glasnost leading to national uprising and collapse have, by overlooking the economy, often ended up one-sided and unconvincing. By returning to the actual debates of perestroika, Miller is able to bring to life the real economic interests that lay behind the laws and reforms of the period.

Miller is also overwhelmingly convincing in his depiction of the 'China connection' and Gorbachev's interest in China as a potential model of reform. His depiction of the influence held by academics in the USSR, moreover, rings true: 'academic research was sent to the highest levels of the Soviet bureaucracy' (p. 84). The use of Soviet academic publications on China and their path to policy makers is also well negotiated in The Struggle to Save the Soviet Economy, with Miller making especially good use of the archival holdings at the Archive of the Russian Academy of Sciences (ARAN).

Notwithstanding its many virtues, however, a close reading of Miller's narrative inevitably leads to the small but worrying feeling that this is all somehow familiar. And in fact it is: Miller's depiction of Gorbachev's struggle to enact reform in the face of entrenched bureaucratic opposition is in many ways strikingly reminiscent of Gorbachev's own account of perestroika. Throughout and after his period of leadership, Gorbachev never tired of declaiming the 'interests' arrayed against him, blaming the ministries and bureaucrats of Moscow for blocking his reforms and ultimately leading to the Soviet collapse. Through the lens of China and its impact on Soviet policy, Miller has come to defend Gorbachev's position, arguing, in essence, that the Soviet collapse had nothing to do with the latter's reforms: had he been given free reign, things might have gone differently. Unfortunately, by aligning himself with Gorbachev's view, Miller has also bound himself to this argument's flaws, empirical and logical alike.

The fundamental empirical problem with Gorbachev's (and Miller's) account of perestroika's failures is its claim that the reform program was blocked from having any real effect. In Miller's telling, 'By 1990, the results of Gorbachev's reforms to trade, enterprises, and agriculture were increasingly outstripped by the fiscal and monetary ramifications of perestroika-era politics' (p. 216). In other words, when reforms had an effect, they were in fact positive - but they were held back by bureaucratic intransigence and in general could not overcome the paralysis of the Soviet state. Yet any detailed analysis of perestroika's economic reforms quickly makes it clear that this account hardly aligns with the period's economic realities. Gorbachev's signature economic reforms - the Law on Enterprises, the Law on Cooperatives, et cetera were in fact all implemented, and moreover had enormous (and enormously negative) impact on the functioning of the Soviet economy.

Nor is this a particularly new empirical issue. During perestroika itself, as Valerii Boldin, one of Gorbachev's close advisors, argued in his memoirs, the more negative effects the reforms brought about, the more Gorbachev accused local actors of 'failing to implement' the reforms.(1) Yet by the final years of the USSR Gorbachev's reforms had in fact taken full effect: cooperatives numbered in the millions, enterprises 
were - in full accordance with the 1987 Law on Enterprises - refusing government contracts and producing fewer and more expensive goods, and both actual production and tax revenues were dropping swiftly. These effects were not, as Miller proposes, the result of the failure of Gorbachev's reforms - but rather the consequence of their implementation. That none of the multitudinous evidence pointing to the reforms' factual implementation and real impact on the Soviet economy found reflection in Miller's work is at least partially, it should be said, a question of sourcing. Based largely on evidence collected, stored, and published by Gorbachev and those who shared his reformist agenda in the 1980s, The Struggle to Save the Soviet Economy is surprisingly light on archival evidence derived from the Soviet Council of Ministers, Gosplan, or other sources that could be balanced against the perspective of those promoting reforms.(2) It quickly becomes clear, moreover, that those figures like Gorbachev and Anatoly Chernyaev, Gorbachev's one-time foreign policy advisor and now, under the auspices of the Gorbachev Foundation in Moscow, the keeper of his reputation, tend to emphasize the positive aspects of reform and their 'failure' to implement change.

If The Struggle to Save the Soviet Economy had included a more critical analysis of the arguments made by Gorbachev and his advisors in light of the actual trajectory of perestroika's reforms, this would have made for a fascinating depiction of the gap that can sometimes arise between economic policy and economic reality. Nor would this have undermined Miller's focus on the China connection, for here too Gorbachev and his advisors seemed to be missing certain key details. Following Gorbachev, Miller argues that China and the USSR started from more or less the same position in the early 1980s: enterprises were entirely state controlled and their profits sent entirely to the state budget. Yet while this may have remained true in China until Deng Xiaoping, it had not been the case in the USSR since at least 1965, when the famous Kosygin reforms, if nothing else, shifted a portion of enterprise profits to individual factories. When 'China posted a decade of impressive GDP growth after it began market reforms in the late 1970s' (p. 222) this at least partially represented the same type of growth already experienced by the USSR in the immediate period after the Kosygin reforms. Assuming that the USSR, which had already passed through some of the same reforms and was essentially operating from a very different starting point, would have the same results as China was to either overlook obvious facts or adhere to a very odd logic.

By binding his argument to Gorbachev's narrative and the comparison to China, Miller also ends up in something of a logical quandary. Insofar as he argues against the real impact of perestroika reforms, he is left to emphasize inflation and debt as the final cause of Soviet economic and even political collapse. This begs the question of timing: Miller is still left to explain why the collapse happened exactly when it did after all, the monetary issues faced by the USSR had existed to one degree or another for decades.(3) If perestroika was essentially causally moot, it seems unclear why debt and deficit borrowing took over exactly when they did. Here the lack of alternative factors looms large - for a book about Gorbachev and perestroika, the almost complete absence of any discussion about glasnost, or nationalist movements, or the republics outside of Moscow seems striking. While economics may very well have been at the heart of perestroika and the Soviet collapse - an argument Miller makes clearly and well - there were additional factors that helped to midwife the collapse at the moment it occurred. Ultimately, Miller's work goes a great distance in bettering our knowledge and understanding of the politics behind the Soviet economic collapse; a slightly more critical and less singularly focused perspective, it might be argued, could have gone even further.

\section{Notes}

1. V. I. Boldin, Krushenie p'edestala. Shtrikhi k portretu M.S. Gorbachevu (Moscow, 1995).Back to (1)

2. This does not include the references to ARAN, which are largely related to academic analyses of China. When it comes to perestroika reforms, Miller relies for the most part upon the Archive of the Gorbachev Foundation, the Politbureau notes published by the same organization, and the data published by Yegor Gaidar from his own work about the Soviet collapse. Citations to GARF or RGAE that do not pass through the former archives are sparse. Back to (2)

3. David Woodruff, Money Unmade: Barter and the Fate of Russian Capitalism (Ithaca, NY, 2000). Back to (3) 


\section{Other reviews:}

\section{$\mathrm{H}-\mathrm{Net}$}

https://networks.h-net.org/node/1883/pages/144668/new-book-struggle-save-soviet-economy-mikhailgorbachev-and-collapse [2]

\section{Source URL:https://reviews.history.ac.uk/review/2066}

\section{Links}

[1] https://reviews.history.ac.uk/item/252204 [2] https://networks.h-net.org/node/1883/pages/144668/newbook-struggle-save-soviet-economy-mikhail-gorbachev-and-collapse 